\title{
Pleurodesis in malignant pleural effusions: Outcome and predictors of success
}

\author{
Hind Rafei ${ }^{1}$, Suha Jabak ${ }^{2}$, Alain Mina ${ }^{3}$ and Arafat Tfayli ${ }^{2 *}$ \\ ${ }^{1}$ Department of Internal Medicine, George Washington University Hospital, USA \\ ${ }^{2}$ Department of Internal Medicine, American University of Beirut Medical Center, Lebanon \\ ${ }^{3}$ Department of Internal Medicine, Kansas University Medical Center, USA
}

\begin{abstract}
Malignant pleural effusion is a common clinical problem in cancer patients. Many therapeutic techniques have been investigated, including pleurodesis. Little is known about the factors that may affect the success rate of such a procedure. The main objective of this study is to assess the success rates of pleurodesis performed on malignant pleural effusions in cancer patients at AUBMC and to identify the predictors of a successful pleurodesis. Patients diagnosed with malignant pleural effusions and who have undergone pleurodesis between years 2004 and 2013 at the American University of Beirut Medical Center were identified. Relevant information including patient, tumor and pleural effusion characteristics and outcome after pleurodesis was recorded. Data analysis was done to assess the success rate of pleurodesis as well as for the presence of statistically significant association between success of pleurodesis and the different clinical characteristics. Pleurodesis success rates were as follow: $17.7 \%$ had complete success, $12.9 \%$ had partial success, $40.3 \%$ had failed pleurodesis, $3.2 \%$ died shortly after pleurodesis, and $25.8 \%$ were lost to follow-up. When this failure rate was further analyzed in terms of the different clinical markers, only two parameters were found to be associated with different success rates of pleurodesis, namely the mean $\mathrm{pH}$ of the pleural fluid and the tube used to perform pleurodesis. The conclusions of this study will benefit future cancer patients presenting with malignant effusions. Based on this study's results a well as those of future studies, clinicians will cautiously plan the management of malignant pleural effusion and also refine the technique used.
\end{abstract}

\section{Introduction}

Malignant pleural effusion is a common clinical problem in patients with neoplastic diseases. Approximately half of the patients with metastatic cancers develop malignant effusions [1] and it can complicate nearly all malignancies [2]. Lung carcinoma is the most common primary tumor type causing malignant pleural effusions, followed by breast cancer and lymphomas; ovarian and gastrointestinal cancers are less commonly involved [3]. The incidence of malignant pleural effusion cases reaches around 150,000 per year in the United States [4].

The most common presenting symptom of pleural effusion is dyspnea followed by cough and chest discomfort [4]. Drainage of the effusion and prevention of recurrence and thereby of symptoms are the two main aims of management. Pleurodesis would avoid the need for repeated hospitalization for thoracocentesis [1] especially that patients with metastatic cancers are having, nowadays, longer life expectancies $[2]$.

Many therapeutic options targeting malignant effusions have been developed of which pleurodesis has been found to be quite effective [5]. Pleurodesis causes elimination of pleural space and theoretically leading to permanent cessation of fluid collection as a result of the formation of fibrous adhesion between the lung and parietal pleura [6]. The efficacy of chemical pleurodesis rests mainly on the performance of an adequate technique allowing complete drainage of the pleural fluid, a total re-expansion of the underlying lung, and consistent adhesion of both pleural surfaces as defined by Martinez et al. [7]

The methods of pleurodesis include intrapleural instillation of a sclerosing agent using a chest tube or videothoracoscopy or surgical abrasion using dry gauze [8]. Both methods were shown to be of equal effectiveness [3]. Among the sclerosants used, talc either aerolized or slurry is the agent used commonly at the present time and it has achieved the best results [8].

However, as in any other medical procedure, chemical pleurodesis has its reported complications. West et al. discussed three potential complications: fever, pain, and most importantly respiratory failure. The latter is thought to be dose dependent [9]. Other adverse effects include hypoxia, dyspnea, and pulmonary edema [9].

Ample research has been conducted targeting optimal pleurodesis strategy; however little has been investigated concerning what factors may affect the success rate of such a procedure. The aim of this study is to identify the success rates of pleurodesis performed on malignant pleural effusions in cancer patients at the American University of Beirut Medical Center and to determine the predictors of successful pleurodesis of malignant effusions.

\section{Materials and methods}

In this retrospective study, all patients diagnosed with malignant pleural effusion who presented to the American University of Beirut

Correspondence to: Arafat Tfayli, Department of Internal Medicine, American University of Beirut Medical Center, PO Box: 11-0236, Riad El Solh, Beirut 1107 2020, Beirut- Lebanon, Tel: +961-1-374374, Fax: +961-1-370814, E-mail: at35@aub.edu.lb

Received: August 25, 2015; Accepted: September 14, 2015; Published: September 18, 2015 
Medical Center (AUBMC) between 2004 and 2013 for pleurodesis and for whom records were available were included. Records were searched for the following parameters: demographics: age and sex; cancer characteristics including location and histology; pleural effusion characteristics including time to diagnosis, time to drainage, drainage method, $\mathrm{pH}$ value, glucose level, $\mathrm{LDH}$ level, all at the time of diagnosis; radiographic characteristics of the pleural effusion: laterality and size; pleurodesis characteristics including technique, type of sclerosant used, dose, time from diagnosis of effusion, time from drainage of effusion, tube used for drainage, time for tube removal and amount drained.

Descriptive analyses, including the numbers and percentages for categorical variables and mean and standard deviations for continuous variables, were tabulated and reported here. Data was analyzed using SPSS. Pleurodesis success was assessed as follow:

- $\quad$ Complete success: Long-term relief of symptoms related to the effusion, with absence of fluid reaccumulation on chest radiographs until death.

- Partial success: Diminution of dyspnea related to the effusion, with only partial reaccumulation of fluid (less than $50 \%$ of the initial radiographic evidence of fluid) with no further therapeutic thoracenteses required for the remainder of patient's life.

- Failed pleurodesis: Lack of success as defined above.

The association between the success rate of pleurodesis and the different patient, tumor, pleural effusion and pleurodesis characteristics was carried out using the Chi-square test for categorical variables and the ANOVA test for continuous variables.

\section{Results}

62 patients were included in the study of which $58.1 \%$ were females. The mean age at diagnosis with cancer was 58.9 years old. The most common site of the primary tumor was the lung $(41.9 \%)$ followed by the breast (17.7\%) with the most common histologies being lung adenocarcinoma (30.6\%) followed by infiltrating ductal carcinoma (17.7\%). As for the pleural effusion, the mean time from diagnosis of cancer to that of pleural effusion is 19.5 months and that from diagnosis of effusion to its drainage of effusion is 13.9 months. The majority of pleural effusions was located on the right and was large in size as reported by radiographic imaging. Only 8 patients underwent $\mathrm{pH}$ testing on the effusion and the mean $\mathrm{pH}$ was 7.68. While most patients, on the other hand, underwent glucose and LDH testing on the effusion and the mean values were 110.2 and 428.2 respectively. Most effusions $(45.2 \%)$ were initially drained by pigtail. Concerning the pleurodesis, the mean time from diagnosis of effusion to pleurodesis was 34.1 days and that from drainage of effusion to pleurodesis was 10.8 days. Chemical pleurodesiswas most commonly performed (75.8\%) with sclerosants used being tetracycline $(34.8 \%)$, bleomycin $(30.4 \%)$, tetracycline and bleomycin (21.7\%) and talc (13\%). Different doses of tetracycline were used including $1500 \mathrm{mg}$ (7.7\%), $1000 \mathrm{mg}$ (76.9\%), $750 \mathrm{mg}(11.5 \%)$ and $250 \mathrm{mg}(3.9 \%)$. Bleomycindose was $60 \mathrm{mgs}$ and talc dose was 5 grams. The tube used to perform pleurodesis was either a pigtail $(54.8 \%)$ or a chest tube $(41.9 \%)$. The mean time to removal of tube after pleurodesis was 33.6 hours with $153.3 \mathrm{ml}$ being drained on average upon removal of the tube. The follow up on the patients revealed that $58.1 \%$ of the patients had effusion reaccumulation after pleurodesis was performed, $17.7 \%$ had no reaccumulation at all, $21 \%$ were lost to follow-up and $3.2 \%$ died shortly after pleurodesis. The mean number of times of reaccumulations after pleurodesis was 1.8 times and the mean time to first reaccumulation after pleurodesis was 27.1 days. The majority of the first reaccumulations (38.9\%) were medium in size. $52.8 \%$ of these first reaccumulations required drainage. In $16.7 \%$ of the cases where reaccumulation after pleurodesis occurred, plurodesis was reattempted. In all these cases, pleurodesis was done once only after the first time (Table1).

Pleurodesis success rates were as follow: $17.7 \%$ had complete success, $12.9 \%$ had partial success, $40.3 \%$ had failed pleurodesis, $3.2 \%$ died shortly after pleurodesis, and $25.8 \%$ were lost to follow-up (Figure 1).

The statistical analysis of the association between the success rates of pleurodesis and the different clinical characteristics revealed that there was no statistically significant difference between the different success rate groups in terms of gender as well as the age at diagnosis $(p=0.264$ and 0.893 respectively). In the complete success group, the tumor was mostly infiltrating ductal carcinoma of the breast while in the partial success and the failure group the tumor was in the lung as in the general population but this difference was not statistically significant $(p=0.198)$. The time from diagnosis of cancer to diagnosis of pleural effusion was also not significantly different between the different success groups with $\mathrm{p}=0.989$. Right pleural effusions are the most common in all groups and the difference in laterality was not statistically significant $(\mathrm{p}=0.727)$. The mean $\mathrm{pH}$ was different between the three groups with the complete success group having the highest $\mathrm{pH}$ of 8.00 followed by the failure group $(\mathrm{pH}=7.68)$ and the difference was statistically significant $(\mathrm{p}=0.033)$. On the other hand, there was no statistically significant difference between the different success groups neither in terms of the mean glucose $(p=0.492)$ nor the mean LDH $(p=0.077)$. The association between the size of pleural effusion and success of pleurodesis was not statistically significant $(p=0.395)$ with large pleural effusions being the most prevalent among all success groups. Also, the mean time from diagnosis to drainage of pleural effusion was similar between the different groups $(\mathrm{p}=0.979) .45 .5 \%$ of the completely successful pleurodeses were done by thoracocentesis compared to $44 \%$ of failing pleurodeses and $50 \%$ of the partially successful ones performed using pigtail. This difference however is not statistically significant $(\mathrm{p}=0.610)$.

As for the pleurodesis technique, neither the mean time from diagnosis of effusion to pleurodesis nor the mean time from drainage of effusion to pleurodesis was significantly different between the success groups $(\mathrm{p}=0.782$ and $\mathrm{p}=0.273$ respectively). Also, chemical pleurodesis was mostly performed in all success groups. The use of different sclerosant didn't show a statistically significant association with success rate $(p=0.827)$. The tube used during pleurodesis however, was found to be associated with success rate with $\mathrm{p}=0.033$.

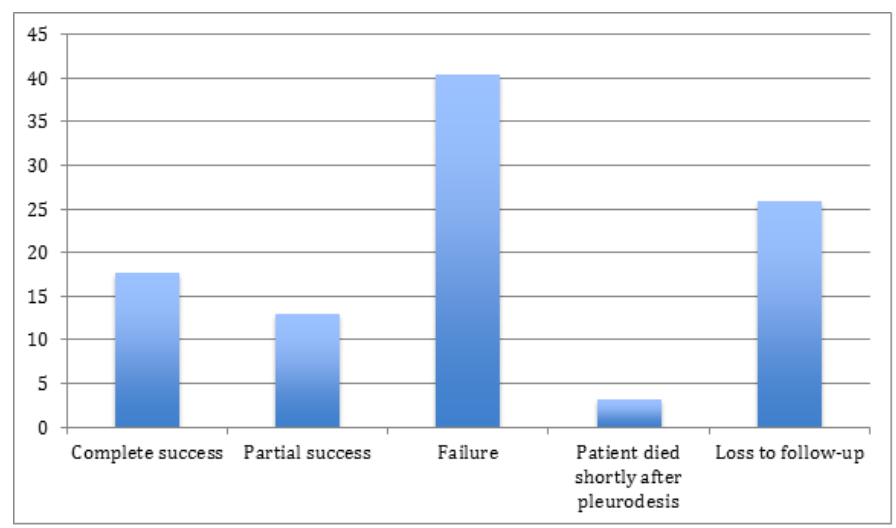

Figure 1. Success rates of pleurodesis. 
Table 1. Patient, tumor, pleural effusion, and pleurodesis characteristics.

\begin{tabular}{|c|c|}
\hline \multicolumn{2}{|c|}{ Patient and Tumor Characteristics } \\
\hline & $N=62$ \\
\hline $\begin{array}{c}\text { Gender }(\%) \\
\text { Female } \\
\text { Male }\end{array}$ & $\begin{array}{l}36(58.1) \\
26(41.9)\end{array}$ \\
\hline Mean age at diagnosis with cancer in years $+/$-SD & $58.90+/-12.41$ \\
\hline \begin{tabular}{|l} 
Primary tumor site (\%) \\
Lung \\
Breast \\
Ovaries \\
Pleura \\
Prostate \\
Hematologic \\
Stomach \\
Others \\
Biliary duct \\
Colon \\
Pancreas \\
Liver \\
Uterus \\
\end{tabular} & $\begin{array}{l}26(41.9) \\
11(17.7) \\
4(6.5) \\
3(4.8) \\
3(4.8) \\
3(4.8) \\
3(4.8) \\
2(3.2) \\
2(3.2) \\
2(3.2) \\
1(1.6) \\
1(1.6) \\
1(1.6)\end{array}$ \\
\hline $\begin{array}{l}\text { Histology }(\%) \\
\text { Lung adenocarcinoma } \\
\text { Lung squamous cell carcinoma } \\
\text { Lung small cell carcinoma } \\
\text { Lung carcinoid tumor } \\
\text { Malignant mesothelioma } \\
\text { Infiltrating ductal carcinoma } \\
\text { Gastric adenocarcinoma } \\
\text { Cholangiocarcinoma } \\
\text { Colonic adenocarcinoma } \\
\text { Pancreatic adenocarcinoma } \\
\text { Gastro-intestinal stromal tumor } \\
\text { Hepatocellular carcinoma } \\
\text { Ovarian adenocarcinoma } \\
\text { Uterine leiomyosarcoma } \\
\text { Prostatic adenocarcinoma } \\
\text { Adrenocortical carcinoma } \\
\text { Waldestrom'smacroglobulinemia } \\
\text { Multiple myeloma } \\
\text { Follicular lymphoma }\end{array}$ & $\begin{array}{l}19(30.6) \\
4(6.5) \\
2(3.2) \\
1(1.6) \\
3(4.8) \\
11(17.7) \\
3(4.8) \\
2(3.2) \\
2(3.2) \\
2(3.2) \\
1(1.6) \\
1(1.6) \\
4(6.5) \\
1(1.6) \\
2(3.2) \\
1(1.6) \\
1(1.6) \\
1(1.6) \\
1(1.6)\end{array}$ \\
\hline
\end{tabular}

Mean time from diagnosis of cancer to diagnosis of pleural $19.49+/-36.45$ effusion in months $+/$-SD

\begin{tabular}{|c|c|}
\hline $\begin{array}{l}\text { Laterality (\%) } \\
\text { Right } \\
\text { Left } \\
\text { Bilateral }\end{array}$ & $\begin{array}{l}29(46.77) \\
22(35.48) \\
11(17.74)\end{array}$ \\
\hline $\begin{array}{l}\text { Chemistry } \\
\text { Mean pH+/-SD }(\mathrm{N}=8) \\
\text { Mean Glucose in } \mathrm{mg} / \mathrm{dl}+/-\mathrm{SD}(\mathrm{N}=46) \\
\text { Mean LDH+/-SD }(\mathrm{N}=49)\end{array}$ & $\begin{array}{l}7.68+/-0.17 \\
110.15+/-48.66 \\
428.18+/-398.08\end{array}$ \\
\hline \begin{tabular}{|c} 
Size $(\%)$ \\
Small \\
Medium \\
Large \\
Missing \\
\end{tabular} & $\begin{array}{l}6(9.68) \\
12(19.35) \\
39(62.9) \\
5(8.06)\end{array}$ \\
\hline $\begin{array}{l}\text { Mean time from diagnosis to drainage of pleural effusion in } \\
\text { days }+/ \text {-SD }(\mathrm{N}=61)\end{array}$ & $13.93+/-26.81$ \\
\hline \begin{tabular}{|l} 
Drainage method (\%) \\
Thoracocentesis \\
Pigtail \\
Chest tube \\
Missing
\end{tabular} & $\begin{array}{l}18(29.03) \\
28(45.16) \\
14(22.58) \\
2(3.23)\end{array}$ \\
\hline $\begin{array}{l}\text { Mean time from diagnosis of effusion to pleurodesis in days }+/- \\
\text { SD }(N=58)\end{array}$ & $34.05+/-85.88$ \\
\hline $\begin{array}{l}\text { Mean time from drainage of effusion to pleurodesis in days }+/- \\
\mathrm{SD}(\mathrm{N}=57)\end{array}$ & $10.84+/-15.74$ \\
\hline $\begin{array}{l}\text { Technique }(\%) \\
\text { Chemical } \\
\text { Mechanical } \\
\text { Missing }\end{array}$ & $\begin{array}{l}47(75.81) \\
9(14.52) \\
6(9.68)\end{array}$ \\
\hline
\end{tabular}

\begin{tabular}{|c|c|}
\hline \multicolumn{2}{|l|}{ Chemical pleurodesis $(\mathrm{N}=46)(\%)$} \\
\hline Type of sclerosant used & \\
\hline Tetracycline & $16(34.78)$ \\
\hline Bleomycin & $14(30.43)$ \\
\hline Tetracycline and bleomycin & $10(21.74)$ \\
\hline Talc & $6(13.04)$ \\
\hline \multicolumn{2}{|l|}{ Dose of tetracycline $(\mathrm{N}=26)$} \\
\hline $1500 \mathrm{mg}$ & $2(7.69)$ \\
\hline $1000 \mathrm{mg}$ & $20(76.92)$ \\
\hline $750 \mathrm{mg}$ & $3(11.54)$ \\
\hline $250 \mathrm{mg}$ & $1(3.85)$ \\
\hline \multicolumn{2}{|l|}{ Dose of bleomycin $(\mathrm{N}=24)$} \\
\hline $60 \mathrm{mg}$ & $23(95.83)$ \\
\hline $50 \mathrm{mg}$ & $1(4.17)$ \\
\hline \multicolumn{2}{|l|}{ Dose of Talc $(\mathrm{N}=6)$} \\
\hline $5 \mathrm{~g}$ & $6(100)$ \\
\hline \multicolumn{2}{|l|}{ Tube used (\%) } \\
\hline Pigtail & $34(54.8)$ \\
\hline Chest tube & $26(41.9)$ \\
\hline Missing & $2(3.2)$ \\
\hline $\begin{array}{l}\text { Mean time to removal of tube after pleurodesis in hours }+/ \text {-SD } \\
(\mathrm{N}=50)\end{array}$ & $\begin{array}{l}33.58+/-42.47 \\
1(1.61)\end{array}$ \\
\hline $\begin{array}{l}\text { Not applicable because patient died prior to tube } \\
\text { removal }(\%)\end{array}$ & $11(17.74)$ \\
\hline \multicolumn{2}{|l|}{ Missing $(\%)$} \\
\hline $\begin{array}{l}\text { Mean amount of drainage when chest tube is removed in } \mathrm{ml}+/- \\
\mathrm{SD}(\mathrm{N}=30)\end{array}$ & $153.33+/-244.43$ \\
\hline \multicolumn{2}{|l|}{ Reaccumulation (\%) } \\
\hline Yes & $36(58.06)$ \\
\hline No & $11(17.74)$ \\
\hline Loss to follow up & $13(20.97)$ \\
\hline Patient died shortly after pleurodesis & $2(3.23)$ \\
\hline $\begin{array}{l}\text { Mean number of times of reaccumulations after pleurodesis }+/- \\
\text { SD }(\mathrm{N}=36)\end{array}$ & $1.78+/-1.46$ \\
\hline $\begin{array}{l}\text { Mean time to first reaccumulation after pleurodesis in days }+/ \text {-SD } \\
(\mathrm{N}=34)\end{array}$ & $27.09+/-53.36$ \\
\hline \multicolumn{2}{|l|}{ Size of first reaccumulation $(\mathrm{N}=36)(\%)$} \\
\hline Small & $6(16.67)$ \\
\hline Medium & $14(38.89)$ \\
\hline Large & $9(25)$ \\
\hline Missing & $7(19.44)$ \\
\hline \multicolumn{2}{|l|}{ First reaccumulation required drainage $(\mathrm{N}=36)(\%)$} \\
\hline Yes & $19(52.78)$ \\
\hline No & $14(38.89)$ \\
\hline Missing & $3(8.33)$ \\
\hline \multicolumn{2}{|l|}{ Pleurodesis attempted after first $(\mathrm{N}=36)(\%)$} \\
\hline Yes & $6(16.67)$ \\
\hline No & $30(83.33)$ \\
\hline $\begin{array}{l}\text { Number of times of pleurodesis after first }(\mathrm{N}=6)(\%) \\
1\end{array}$ & $6(100)$ \\
\hline
\end{tabular}

$70.8 \%$ of failed pleurodeses were performed using a pigtail while $63.6 \%$ of the completely successful pleurodeses were performed using a chest tube. Finally, both the mean time to removal of tube after pleurodesis and the amount drained at that time were not associated with success of pleurodesis with $\mathrm{p}=0.767$ and 0.198 respectively (Table2).

\section{Discussion}

Different studies have tackled the predictors of success of pleurodesis for malignant pleural effusion in different clinical settings and as related to different factors. The results of these many studies available in the literature vary widely. The statistical distribution of malignant effusions among the different cancers in this study resembles that in the literature. Lung carcinoma followed by breast carcinoma is the leading cause of malignant effusions [10-12]. In this study, lung adenocarcinoma was the most prevalent histology among patient who underwent pleurodesis for malignant pleural effusion (in $30.6 \%$ of patients) followed by infiltrating ductal carcinoma of the breast (in $17.7 \%)$. 
Table 2. Association between success rates of pleurodesis and the different clinical characteristics.

\begin{tabular}{|c|c|c|c|c|c|}
\hline Clinical Characteristics & $\begin{array}{l}\text { All } \\
N=44\end{array}$ & $\begin{array}{l}\text { Complete Success } \\
\mathbf{N}=\mathbf{1 1}\end{array}$ & $\begin{array}{l}\text { Partial Success } \\
\mathbf{N}=\mathbf{8}\end{array}$ & $\begin{array}{l}\text { Failure } \\
\mathbf{N}=\mathbf{2 5}\end{array}$ & P-value \\
\hline \multicolumn{6}{|l|}{ Patient characteristics } \\
\hline Male gender & $15(34.09)$ & $5(45.45)$ & $4(50)$ & $6(24)$ & 0.264 \\
\hline Age at diagnosis with cancer (yrs) & $58.34+/-12.53$ & $59.45+/-12.97$ & $56.63+/-11.92$ & $58.40+/-12.96$ & 0.893 \\
\hline Primary tumor site & & & & & 0.198 \\
\hline $\begin{array}{l}\text { Lung } \\
\text { Breast } \\
\text { Ovaries } \\
\text { Pleura } \\
\text { Prostate } \\
\text { Hematologic } \\
\text { Stomach } \\
\text { Others } \\
\text { Biliary duct } \\
\text { Colon } \\
\text { Liver } \\
\text { Uterus } \\
\text { Pancreas }\end{array}$ & $\begin{array}{l}16(36.36) \\
9(20.45) \\
3(6.82) \\
3(6.82) \\
2(4.55) \\
2(4.55) \\
1(2.27) \\
1(2.27) \\
2(4.55) \\
2(4.55) \\
1(2.27) \\
1(2.27) \\
1(2.27)\end{array}$ & $\begin{array}{l}2(18.18) \\
3(27.27) \\
1(9.09) \\
2(18.18) \\
1(9.09) \\
2(18.18) \\
0(0) \\
0(0) \\
0(0) \\
0(0) \\
0(0) \\
0(0) \\
0(0)\end{array}$ & $\begin{array}{l}2(25) \\
1(12.5) \\
0(0) \\
0(0) \\
1(12.5) \\
0(0) \\
1(12.5) \\
0(0) \\
1(12.5) \\
1(12.5) \\
0(0) \\
0(0) \\
1(12.5)\end{array}$ & $\begin{array}{l}12(48) \\
5(20) \\
2(8) \\
1(4) \\
0(0) \\
0(0) \\
0(0) \\
1(4) \\
1(4) \\
1(4) \\
1(4) \\
1(4) \\
0(0)\end{array}$ & \\
\hline Histology & & & & & 0.213 \\
\hline $\begin{array}{l}\text { Lung adenocarcinoma } \\
\text { Lung squamous cell carcinoma } \\
\text { Lung small cell carcinoma } \\
\text { Malignant mesothelioma } \\
\text { Infiltrating ductal carcinoma } \\
\text { Gastric adenocarcinoma } \\
\text { Cholangiocarcinoma } \\
\text { Colonic adenocarcinoma } \\
\text { Pancreatic adenocarcinoma } \\
\text { Gastro-intestinal stromal tumor } \\
\text { Hepatocellular carcinoma } \\
\text { Prostatic adenocarcinoma } \\
\text { Ovarian adenocarcinoma } \\
\text { Uterine leiomyosarcoma } \\
\text { Multiple myeloma } \\
\text { Follicular lymphoma }\end{array}$ & $\begin{array}{l}12(27.27) \\
3(6.82) \\
1(2.27) \\
3(6.82) \\
8(18.18) \\
1(2.27) \\
2(4.55) \\
2(4.55) \\
1(2.27) \\
1(2.27) \\
1(2.27) \\
2(4.55) \\
3(6.82) \\
1(2.27) \\
1(2.27) \\
1(2.27)\end{array}$ & $\begin{array}{l}2(18.18) \\
0(0) \\
0(0) \\
2(18.18) \\
3(27.27) \\
0(0) \\
0(0) \\
0(0) \\
0(0) \\
0(0) \\
0(0) \\
1(9.09) \\
1(9.09) \\
0(0) \\
1(9.09) \\
1(9.09)\end{array}$ & $\begin{array}{l}1(12.5) \\
0(0) \\
1(12.5) \\
0(0) \\
1(12.5) \\
1(12.5) \\
1(12.5) \\
1(12.5) \\
1(12.5) \\
0(0) \\
0(0) \\
1(12.5) \\
0(0) \\
0(0) \\
0(0) \\
0(0)\end{array}$ & $\begin{array}{l}9(36) \\
3(12) \\
0(0) \\
1(4) \\
5(20) \\
0(0) \\
1(4) \\
1(4) \\
0(0) \\
1(4) \\
1(4) \\
0(0) \\
2(8) \\
1(4) \\
0(0) \\
0(0)\end{array}$ & \\
\hline \multicolumn{6}{|l|}{ Pleural effusion } \\
\hline $\begin{array}{l}\text { Time from diagnosis of cancer to diagnosis of } \\
\text { pleural effusion (months) }\end{array}$ & $22.53+/-41.86$ & $21.55+/-21.72$ & $21.27+/-23.08$ & $23.37+/-52.78$ & 0.989 \\
\hline $\begin{array}{l}\text { Laterality } \\
\text { Right } \\
\text { Left } \\
\text { Bilateral }\end{array}$ & $\begin{array}{l}23(52.3) \\
16(36.4) \\
5(11.4)\end{array}$ & $\begin{array}{l}6(54.5) \\
3(27.3) \\
2(18.2)\end{array}$ & $\begin{array}{l}4(50) \\
4(50) \\
0(0)\end{array}$ & $\begin{array}{l}13(52) \\
9(36) \\
3(12)\end{array}$ & 0.727 \\
\hline Mean pH & $\begin{array}{l}N=7 \\
7.68+/-0.18\end{array}$ & $\begin{array}{l}\mathrm{N}=1 \\
8.00+/-0.00\end{array}$ & $\begin{array}{l}\mathrm{N}=2 \\
7.52+/-0.01\end{array}$ & $\begin{array}{l}\mathrm{N}=4 \\
7.68+/-0.11\end{array}$ & 0.033 \\
\hline Mean Glucose (mg/dl) & $\begin{array}{l}N=33 \\
108.85+/-54.26\end{array}$ & $\begin{array}{l}\mathrm{N}=9 \\
122.44+/-57.45\end{array}$ & $\begin{array}{l}\mathrm{N}=6 \\
119.83+/-48.27\end{array}$ & $\begin{array}{l}\mathrm{N}=18 \\
98.39+/-55.21\end{array}$ & 0.492 \\
\hline Mean LDH & $\begin{array}{l}\mathrm{N}=35 \\
439.23+/-417.61\end{array}$ & $\begin{array}{l}\mathrm{N}=8 \\
276.88+/-251.77\end{array}$ & $\begin{array}{l}\mathrm{N}=6 \\
207.67+/-91.42\end{array}$ & $\begin{array}{l}\mathrm{N}=21 \\
567.24+/-477.88\end{array}$ & 0.077 \\
\hline $\begin{array}{l}\text { Size } \\
\quad \text { Small } \\
\text { Medium } \\
\text { Large }\end{array}$ & $\begin{array}{l}3(7.5) \\
7(17.5) \\
30(75)\end{array}$ & $\begin{array}{l}0(0) \\
1(10) \\
9(90)\end{array}$ & $\begin{array}{l}0(0) \\
1(12.5) \\
7(87.5)\end{array}$ & $\begin{array}{l}3(13.6) \\
5(22.7) \\
14(63.6)\end{array}$ & 0.395 \\
\hline $\begin{array}{l}\text { Mean time from diagnosis to drainage of pleural } \\
\text { effusion (days) }\end{array}$ & $13.34+/-18.67$ & $14.36+/-20.21$ & $12.88+/-19.95$ & $13.04+/-18.38$ & 0.979 \\
\hline $\begin{array}{l}\text { Drainage method } \\
\text { Thoracocentesis } \\
\text { Pigtail } \\
\text { Chest tube } \\
\end{array}$ & $\begin{array}{l}15(34.1) \\
19(43.2) \\
10(22.7)\end{array}$ & $\begin{array}{l}5(45.5) \\
4(36.4) \\
2(18.2)\end{array}$ & $\begin{array}{l}1(12.5) \\
4(50) \\
3(37.5)\end{array}$ & $\begin{array}{l}9(36) \\
11(44) \\
5(20)\end{array}$ & 0.610 \\
\hline \multicolumn{6}{|l|}{ Pleurodesis characteristics } \\
\hline $\begin{array}{l}\text { Mean time from diagnosis of effusion to } \\
\text { pleurodesis (days) }\end{array}$ & $\begin{array}{l}\mathrm{N}=43 \\
37.93+/-96.46\end{array}$ & $\begin{array}{l}\mathrm{N}=11 \\
30.18+/-30.01\end{array}$ & $\begin{array}{l}\mathrm{N}=8 \\
21.5+/-20.33\end{array}$ & $\begin{array}{l}N=24 \\
46.96+/-127.53\end{array}$ & 0.782 \\
\hline $\begin{array}{l}\text { Mean time from drainage of effusion to } \\
\text { pleurodesis (days) }\end{array}$ & $\begin{array}{l}\mathrm{N}=42 \\
12.62+/-17.78\end{array}$ & $\begin{array}{l}\mathrm{N}=11 \\
20.00+/-24.94\end{array}$ & $\begin{array}{l}\mathrm{N}=8 \\
8.5+/-13.75\end{array}$ & $\begin{array}{l}\mathrm{N}=23 \\
10.52+/-14.44\end{array}$ & 0.273 \\
\hline $\begin{array}{l}\text { Technique } \\
\text { Chemical } \\
\text { Mechanical }\end{array}$ & $\begin{array}{l}33(82.5) \\
7(17.5)\end{array}$ & $\begin{array}{l}8(72.7) \\
3(27.3)\end{array}$ & $\begin{array}{l}5(62.5) \\
3(37.5)\end{array}$ & $\begin{array}{l}20(95.2) \\
1(4.8)\end{array}$ & 0.071 \\
\hline
\end{tabular}




\begin{tabular}{|c|c|c|c|c|c|}
\hline \begin{tabular}{|l} 
Type of sclerosant used \\
Tetracycline \\
Bleomycin \\
Tetracycline and bleomycin \\
Talc
\end{tabular} & $\begin{array}{l}10(31.2) \\
10(31.2) \\
7(21.9) \\
5(15.6)\end{array}$ & $\begin{array}{l}1(12.5) \\
3(37.5) \\
3(37.5) \\
1(12.5)\end{array}$ & $\begin{array}{l}2(40) \\
1(20) \\
1(20) \\
1(20)\end{array}$ & $\begin{array}{l}7(36.8) \\
6(31.6) \\
3(15.8) \\
3(15.8)\end{array}$ & 0.827 \\
\hline $\begin{array}{l}\text { Tube used } \\
\text { Pigtail } \\
\text { Chest tube }\end{array}$ & $\begin{array}{l}23(53.5) \\
20(46.5)\end{array}$ & $\begin{array}{l}4(36.4) \\
7(63.6)\end{array}$ & $\begin{array}{l}2(25) \\
6(75)\end{array}$ & $\begin{array}{l}17(70.8) \\
7(29.2)\end{array}$ & 0.033 \\
\hline $\begin{array}{l}\text { Mean time to removal of tube after pleurodesis } \\
\text { (hours) }\end{array}$ & $\begin{array}{l}\mathrm{N}=38 \\
32.92+/-37.63\end{array}$ & $\begin{array}{l}\mathrm{N}=9 \\
34.44+/-36.15\end{array}$ & $\begin{array}{l}\mathrm{N}=8 \\
40.75+/-40.48\end{array}$ & $\begin{array}{l}\mathrm{N}=21 \\
29.29+/-38.52\end{array}$ & 0.767 \\
\hline $\begin{array}{l}\text { Mean amount of drainage when chest tube is } \\
\text { removed }(\mathrm{ml})\end{array}$ & $\begin{array}{l}\mathrm{N}=18 \\
111.11+/-163.08\end{array}$ & $\begin{array}{l}\mathrm{N}=7 \\
153.57+/-170.12\end{array}$ & $\begin{array}{l}\mathrm{N}=4 \\
187.50+/-246.22\end{array}$ & $\begin{array}{l}\mathrm{N}=7 \\
25.00+/-38.19\end{array}$ & 0.198 \\
\hline
\end{tabular}

While this study aims at revealing the predictors of success of pleurodesis for malignant pleural effusion at the American University of Beirut Medical Center, the number of cases studied remains the main limitation of a thorough statistical analysis. Pleurodesis for malignant pleural effusion is not a frequently performed procedure and this is apparent in the number of patients accrued in different studies about the procedure. In a study of the early and late mortality rates after pleurodesis for malignant pleural effusion, the number of patients who performed pleurodesis for that purpose between March 1, 1996 and January 31, 2001 was 70 patients [13]. In a review by Shaw et al. about pleurodesis for malignant effusions, the number of patients studied in individual RCTs included in the meta-analysis ranges from 19 to 106 [1].

The analysis of the success rates of pleurodesis for malignant pleural effusion at AUBMC revealed that the procedure mostly failed (40.3\%) with failure being defined as reaccumulation of more than $50 \%$ of the initial fluid as shown upon imaging. When this failure rate was further analyzed in terms of the different clinical markers, only two parameters were found to be associated with different success rates of pleurodesis, namely the mean $\mathrm{pH}$ of the pleural fluid and the tube used to perform pleurodesis. The complete success group had the highest $\mathrm{pH}$ as well as chest tube used mostly. In an Egyptian study about the pleural effusion biomarkers as predictors of success of chemical pleurodesis, it was found that the success of pleurodesis is higher when the $\mathrm{pH}$ and glucose levels are high and the LDH level is low [14]. While our study revealed very similar results as the complete success group had higher $\mathrm{pH}$ and glucose level and lower LDH level than the failure group, statistical significance was revealed only for the $\mathrm{pH}$. The American Thoracic Society/European Respiratory Society guideline for the management of MPE recommends that pleurodesis should be limited to patients with pleural fluid $\mathrm{pH}$ values greater than 7.30, because of the direct correlation between low $\mathrm{pH}$ and poor shortterm survival [15-17]. This was not found to be the case in a European study that showed no association between success and $\mathrm{LDH}$ and $\mathrm{pH}$ [18]. In another Egyptian study that compared the success of different techniques of pleurodesis for malignant pleural effusion, the group subjected to pigtail drainage then pleurodesis had a higher frequency of success than the one subjected to tube thoracotomy drainage followed by pleurodesis [19]. This shows opposite results to our study in terms of success according to the catheter used.

The use of different sclerosing agents for chemical pleurodesis yielded insignificantly different complete success rates of $37.5 \%, 37.5 \%$, $12.5 \%$ and $12.5 \%$ for tetracycline and bleomycin together, bleomycin, tetracycline and talc respectively. There are conflicting results from around the world about the effectiveness of the use of a sclerosing agent over another for successful pleurodesis. Shaw et al. in their Cochrane meta-analysis showed that talc was associated with a significantly better chance of success than any other agent [1]. A prospective, randomized trialconcluded that bleomycin is as effective as talc, but the agent iscostly [20]. A meta-analysis comparing talc, bleomycin, tetracycline/ doxycycline, C. parvum extract, and mitozatrone did not find one agent that was significantly better than the others, although the trend was toward better success with talc [21].

The predictors of success of pleurodesis for malignant effusion constitute a controversial field of study that seems to be institution specific. It is worth an in-depth analysis to determine the factors that lead to a successful pleurodesis in every institution in order to increase the complete success rates. A better understanding is warranted knowing that the success rates of pleurodesis in this study as well as in other studies from around the world look dismal. Analyses performed over larger periods of time and on a bigger scale are needed to enhance the statistical power and generate consistent results that can be used as a database to ameliorate performance of this procedure. Finally, both positive and negative association between different factors and success of pleurodesis are important to reveal. The positive associations can lead to installation of better techniques as well as customized guidelines for the indications of its performance. On the other hand, negative results can shift our attention in the choice of a method over another to more effective criteria. For example, since the different sclerosing agents yielded comparable success rates in this study, the cost as well as availability might be more important factors in the choice of the sclerosing agent to be used in our institution.

\section{Conflicts of interests}

No organization has sponsored the research. Authors have full control of all primary data and agree to allow the journal to review their data if requested. The authors declare that they have no conflict of interest to disclose.

\section{References}

1. Shaw P, Agarwal R (2004) Pleurodesis for malignant pleural effusions. Cochrane Database Syst Rev: CD002916. [Crossref]

2. Davies HE, Lee YC (2013) Management of malignant pleural effusions: questions that need answers. Curr Opin Pulm Med 19: 374-379. [Crossref]

3. American Thoracic Society (2000) Management of malignant pleural effusions. Am J Respir Crit Care Med 162: 1987-2001. [Crossref]

4. Gillen J, Lau C (2013) Permanent indwelling catheters in the management of pleural effusions. Thorac Surg Clin23: 63-71, vi. [Crossref]

5. Srour N, Amjadi K, Forster A, Aaron S (2013) Management of malignant pleural effusions with indwelling pleural catheters or talc pleurodesis. Can Respir J 20: 106110. [Crossref]

6. Ukale V, Bone D, Hillerdal G, Cederlund K, Widström O, et al. (1999) The impact of pleurodesis in malignant effusion on respiratory function. Respir Med 93: 898-902. [Crossref]

7. Martínez-Moragón E, Aparicio J, Sanchis J, Menéndez R, Cruz Rogado M, et al. (1998) Malignant pleural effusion: prognostic factors for survival and response to chemical pleurodesis in a series of 120 cases. Respiration 65: 108-113. [Crossref] 
8. Bouros D, Froudarakis M, Siafakas NM (2000) Pleurodesis: everything flows. Chest 118: 577-579. [Crossref]

9. Rehse DH, Aye RW, Florence MG (1999) Respiratory failure following talc pleurodesis. Am J Surg 177: 437-440. [Crossref]

10. Apffelstaedt JP, Van Zyl JA, Muller AG (1995) Breast cancer complicated by pleural effusion: patient characteristics and results of surgical management. J Surg Oncol 58 : 173-175. [Crossref]

11. Johnston WW (1985) The malignant pleural effusion. A review of cytopathologic diagnoses of 584 specimens from 472 consecutive patients. Cancer 56: 905-909. [Crossref]

12. Weichselbaum R, Marck A, Hellman S (1977) Pathogenesis of pleural effusion in carcinoma of the breast. Int J Radiat Oncol Biol Phys 2: 963-965. [Crossref]

13. Bernard A, de Dompsure RB, Hagry O, Favre JP (2002) Early and late mortality after pleurodesis for malignant pleural effusion. Ann Thorac Surg 74: 213-217. [Crossref]

14. Alsayed S, Marzouk S, Abelhalim S, Mousa E (2015) Malignant pleural effusion biomarkers as predictor for chemical pleurodesis success. Egyptian Journal of Chest Diseases and Tuberculosis 64: 153-160.
15. Antony VB, Loddenkemper R, Astoul P (2012) Management of malignant pleural effusions. Am J Respir Crit Care Med 162: 1987-2001. [Crossref]

16. Good JT Jr, Taryle DA, Maulitz RM, Kaplan RL, Sahn SA (1980) The diagnostic value of pleural fluid pH.Chest 78: 55-59. [Crossref]

17. Heffner JE, Nietert PJ, Barbieri C (2000) Pleural fluid $\mathrm{pH}$ as a predictor of survival for patients with malignant pleural effusions. Chest 117: 79-86. [Crossref]

18. Burgers JA, Kunst PW, Koolen MG, Willems LN, Burgers JS, et al. (2008) Pleural drainage and pleurodesis: implementation of guidelines in four hospitals. Eur Respir $J$ 32: 1321-1327. [Crossref]

19. Ghoneim A, Elkomy H, Elshora A, Mehrez M (2014) Usefulness of pigtail catheter in pleurodesis of malignant pleural effusion. Egyptian Journal of Chest Diseases and Tuberculosis 63: 107-112.

20. Zimmer PW, Hill M, Casey K, Harvey E, Low DE (1997) Prospective randomized trial of talc slurry versus bleomycin in pleurodesis for symptomatic malignant pleural effusions. Chest 112: 430-439. [Crossref]

21. Tan C, Sedrakyan A, Browne J, Swift S, Treasure T (2006) The evidence on the effectiveness of management for malignant pleural effusion: a systematic review. Eur J Cardiothorac Surg 29: 829-838. [Crossref]

Copyright: (C) 2015 Rafei H. This is an open-access article distributed under the terms of the Creative Commons Attribution License, which permits unrestricted use, distribution, and reproduction in any medium, provided the original author and source are credited. 